\title{
First Experience in Management of Coronavirus Disease 2019 (COVID-19) in Kidney Transplant Patient - Case Report
}

\author{
Galina Severova ${ }^{1 *}$, Igor Nikolov ${ }^{1}$, Lada Trajceska ${ }^{1}$, Nikola Gjorgjievski ${ }^{1}$, Fadil Cana ${ }^{2}$, Ilir Demiri ${ }^{2}$, Milena Stevanovik ${ }^{2}$,
} Irena Rambabova-Bushljetik ${ }^{1}$, Goce Spasovski ${ }^{1}$

${ }^{1}$ University Clinic of Nephrology, Faculty of Medicine, University "SS Cyril and Methodius", Skopje, Republic of Macedonia; ${ }^{2}$ Univeristy Clinic for Infectious Diseases and Febrile Condition, Faculty of Medicine, University "SS Cyril and Methodius," Skopje, Republic of Macedonia

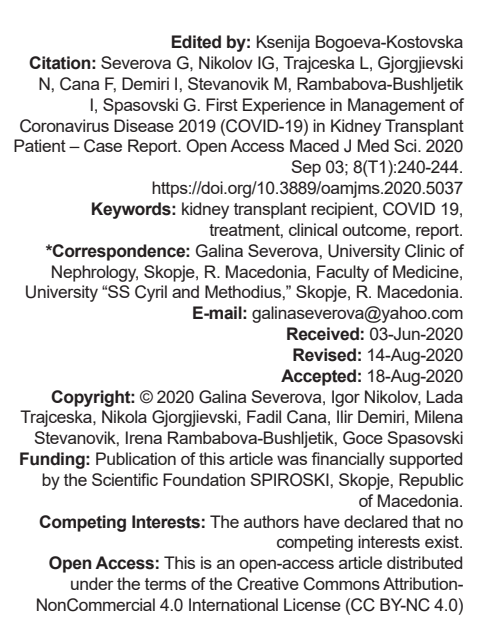

\section{Abstract}

BACKGROUND: Severe acute respiratory syndrome coronavirus 2 (SARS-CoV-2) infection has recently emerged in the world. There are limited data describing the clinical progression of COVID-19 in transplanted patients. In the general population, clinical presentation ranges from asymptomatic infection to severe pneumonia and may also develop renal failure. In kidney transplant (KT) patients, management of these patients was mainly based on anecdotal experience.

CASE REPORT: We report our first experience of KT patients with COVID-19. A 49-year-old male with KT in 2017 presented on March 20, 2020, with fever, weakness, smell loss, chest pain, and caught. On chest X-ray, he presented ground-glass opacities and bilateral pneumonia. There was a slight progression to acute hypoxic respiratory failure. We reduced immunosuppression therapy and since we suspected seasonal flu, we applied available antivira oseltamivir till confirmation of RNA sequence of the SARS-CoV-2 virus. Moreover, we applied azithromycin and broad spectrum of antibiotics as well as an anticoagulant therapy. Graft function remained stable during 14 days of hospitalization. The patient clinically improved with decreasing oxygen requirements and manifested clinical recovery. After two negative PCR test, he was discharged and immunosuppression therapy was returned to previous.

CONCLUSION: This case highlights the importance of earlier outpatient hospitalization and testing which may improve COVID-19 outcomes among transplanted patients.

\section{Introduction}

In December 2019, in Wuhan, China, a new disease appeared that caused severe pneumonia and severe acute respiratory syndrome coronavirus 2 (SARSCoV2) was detected as a causative agent. Disease was called coronavirus disease 2019 (COVID-19). It was spread very fast to all continents, and on March 11, 2020, the World Health Organization (WHO) declared a pandemic [1]. It has been shown that virus was transmitted from person to person during unprotected contact, respiratory droplet, fecal-oral transmission, and vertical transmission from mother to child [2]. Moreover, it was shown that it uses ACE 2 receptors to enter the cell, similar to SARS-CoV. The clinical presentation is very diverse, from asymptomatic, mild, and moderate to severe [3].

Patients with transplanted kidneys are on continuous immunosuppressive therapy. Previous experiences with SARS and MERS have described deteriorating graft function in infections, even with a fatal outcome [4], [5]. At the root of dealing with them, as well as in all infections, is actually timely modifications or discontinuation of immunosuppressive therapy, except for corticosteroids according to the recommendations and appropriate specific therapy [6], [7]. It has been reported that in KT patients with COVID-19, it is necessary to modify the immunosuppressive therapy; unfortunately, there is a lack of reports about appropriate specific therapy for SARS-CoV-2 in KT patients [8], [9], [10].

First imported case of COVID-19 was detected in our country on February 21, 2020, and until May 15, 2020, there were a total number of 1723 patients, 1235 cured, including $1 \mathrm{KT}$ patient and 7 patients on dialysis [11].

\section{Case Report}

We present here our first experience with COVID-19 in a 49-year-old male kidney transplant patient. He was transplanted 3 years ago, and the donor was his brother. Treated according to a protocol with four immunosuppressive therapies, Basiliximab as induction therapy and triple immunosuppressive maintenance 
therapy that included corticosteroids, cyclosporine A (Cy A), and mycophenolic acid (MMF). From comorbidities present arterial hypertension, regulated by the following antihypertensive oral therapy: Calcium antagonist (nifedipine $\mathrm{R}$ a $20 \mathrm{mg} 3 \times 1$ ), angiotensin II receptor blocker $(\mathrm{ARB})$ losartan a $50 \mathrm{mg} 2 \times 1$ and carvedilol a $6.25 \mathrm{mg} 2 \times 1$, and obesity with body mass index $(\mathrm{BMI})=37.7$. The patient regularly came for regular follow-up. No signs of transplant rejection were recorded during follow-up. Kidney function was stable, with values for serum creatinine of $110 \mu \mathrm{mol} / \mathrm{L}$ and calculated GFR of $109 \mathrm{ml} / \mathrm{min}$, on the last control on March 3, 2020. The patient was given to sign a written consent.

On March 20, 2020, the patient experienced the first symptoms such as weakness, pain in the knees and hips, temperature up to $38.5^{\circ} \mathrm{C}$, loss of taste and smell, and chest pain. According to the protocols of our Ministry of Health, the patient called the epidemiological services. Because the patient had a negative epidemiological history, he was referred to his general doctor with suspicion of seasonal flu. Oral treatment with ciprofloxacin a $500 \mathrm{mg} 2^{\circ} 1$ and oseltamivir a $75 \mathrm{mg} 2 \times 1$ (Tamiflu) was started immediately. The dose of cyclosporine $A$ (Cy A) and MMF was reduced by $50 \%$ of baseline.

The temperature persisted and a persistent dry cough appeared, indicating that the patient needs to be tested. On March 23, 2020, a diagnosis of COVID 19 was made by proving the presence of an RNA sequence of the SARS-CoV-2 virus in the material from the nasal and throat swab. The same day, the patient was hospitalized at the University Clinic for Infectious diseases and febrile conditions.

At the time of admission, the patient was febrile $38^{\circ} \mathrm{C}$ and the physical status was positive. The auscultatory chest findings were in favor of sharper vesicular breathing.

The initial laboratory test showed an orderly leukocyte count, but a reduced lymphocyte count slightly elevated $C$ reactive protein $(C R P)$ and creatinine kinase (CK). The graft function was normal, but values for serum potassium were close to the lower limit. The hemostasis finding indicated lower platelet counts and a slight increase in d-dimers (Tables 1 and 2). The chest X-ray showed bilateral pneumonia (Figure 1).

The immunosuppressive therapy $\mathrm{Cy} A$ and MMF were discontinued and oral decortin a $15 \mathrm{mg}$ were given as maintenance therapy. The ARB was interrupted. The rest of the therapy consisted of intravenous ceftriaxone a $2 \mathrm{~g} 2 \times 1$, azithromycin a $500 \mathrm{mg} 1 \times 1$, paracetamol when needed, subcutaneous clexane, and other oral supportive therapy such as Vitamin C, probiotics, potassium supplements, and hepatoprotectants (Table 3 ).

The patient after 9 days was afebrile. Of all the other symptoms, the dry cough lasted longer (Table 4). Regarding the laboratory findings, there has been a
Table 1: Biochemical findings during hospitalization

\begin{tabular}{|c|c|c|c|c|}
\hline ??? & March 24 & March 28 & April 02 & April 04 \\
\hline$\overline{\mathrm{Hb} \mathrm{g} / \mathrm{L}}$ & 141 & 140 & 136 & 138 \\
\hline RBC $10^{\wedge} 12 / \mathrm{L}$ & 4.6 & 4.7 & 4.6 & 4.6 \\
\hline WBC 10^9/L & 4.4 & 7.5 & 7.4 & 5.8 \\
\hline PLT 10^9/L & 123 & 166 & 264 & 259 \\
\hline Htc rv & 0.40 & 0.39 & 0.38 & 0.40 \\
\hline $\mathrm{Ne} 10^{\wedge} 9 / \mathrm{L}$ & 0.84 & 0.87 & 0.67 & 0.63 \\
\hline Ly 10^9/L & 0.08 & 0.07 & 0.16 & 0.20 \\
\hline Mo \% & 0.08 & 0.06 & 0.15 & 0.15 \\
\hline Eo $\%$ & & & 0,02 & 0,02 \\
\hline Glucose mmoll/L & 5.3 & 6.9 & 5.0 & 5.2 \\
\hline Urea mmoll/L & 7,0 & 4,0 & 3,9 & 4,4 \\
\hline Creatinine $/ \mu \mathrm{mol} / \mathrm{L}$ & 100 & 102 & 104 & 97 \\
\hline Tot.bil $\mu \mathrm{moll} / \mathrm{L}$ & 11 & & & \\
\hline Dir/ind $\mu \mathrm{moll} / \mathrm{L}$ & $3 / 8$ & & & \\
\hline ALT U/L & 41 & & 88 & 80 \\
\hline AST U/L & 36 & & 54 & 38 \\
\hline LDH U/L & 161 & 334 & 316 & 244 \\
\hline CK U/L & 239 & 231 & 93 & \\
\hline CK-MB U/L & 14 & 17 & & \\
\hline GGT U/L & & & & 23 \\
\hline Troponin $\mathrm{ng} / \mathrm{ml}$ & 34.6 & & & \\
\hline $\mathrm{K}$ mmoll/L & 3.6 & 3.0 & 2.9 & 3.3 \\
\hline $\mathrm{Na} \mathrm{mmoll} / \mathrm{L}$ & 138 & 133 & 138 & 138 \\
\hline Ca mmoll/L & 2.2 & 2.2 & 2.16 & 2.2 \\
\hline Total proteins $\mathrm{g} / \mathrm{L}$ & 65 & & & \\
\hline Globulins g/L & 29 & & & \\
\hline Albumins $\mathrm{g} / \mathrm{L}$ & 36 & & & \\
\hline CRP mg/L & 45 & 87 & 30 & 6 \\
\hline \multicolumn{5}{|c|}{$\begin{array}{l}\text { Hb: Hemoglobin, RBC: Red blood cell, WBC: White blood cell, PLT: Platelet, Ne: Neutrophils, } \\
\text { Ly: Lymphocytes, Mo: Monocytes, Eo: Eosinophils, Tot.bil: Total bilirubin, dir/ind: Direct/indirect, ALT: } \\
\text { Alanine Transaminase, AST: Aspartate aminotransferase, LDH: Lactate dehydrogenase, CK: Creatine } \\
\text { kinase, CK-MB creatine kinase: MB, GGT: Gamma-glutamyl transferase, K: Kalium, Na: Sodium, Ca: }\end{array}$} \\
\hline
\end{tabular}

continuous improvement in the number of lymphocytes, platelets, as well as serum values for CRP and CC. A moderate increase in d-dimers and moderate transaminase activity also has been observed (Tables 1 and 2). The graft function remained stable with serum creatinine $97 \mu \mathrm{moll} / \mathrm{L}$.

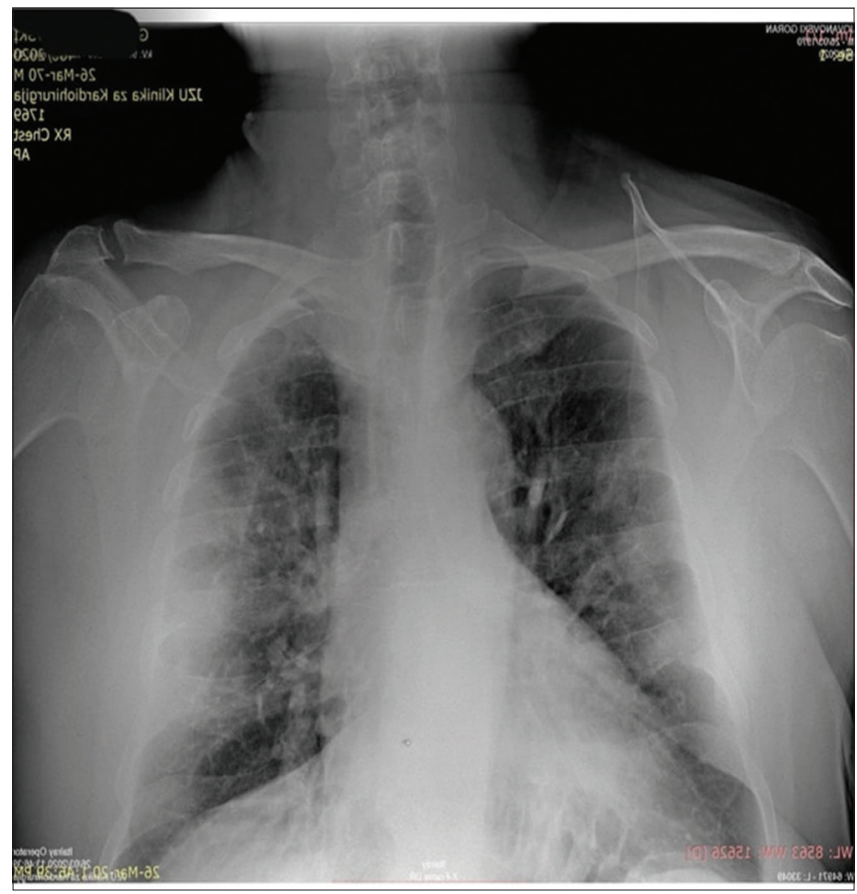

Figure 1: Bilateral pneumonia (chest $X$-ray on the $3^{\text {th }}$ day)

After 15 days of hospitalization and two consecutive negative nasal and throat swab tests for SARS-CoV-2, the patient was discharged. After discharge, the Cy A and MMT therapy were restarted, gradually within 7 days to previous maintenance dosage. On the first control 12 days after hospitalization, renal function was unchanged and chest $X$-ray picture finding showed resolving of pneumonia (Figure 2). 
Table 2: Hemostasis findings during hospitalization

\begin{tabular}{llllll}
\hline Date & PLT & Hematocrit & $\begin{array}{l}\text { Prothrombin time }(\mathrm{s}) \\
(9.8-14.2)\end{array}$ & $\begin{array}{l}\text { Activated partial (s) } \\
(27.9-29.1)\end{array}$ & $\begin{array}{l}\text { Thrombin time }(\mathrm{s}) \\
(16.1-19.01)\end{array}$ \\
\hline March, 24 & 111 & & 10.2 & 29.1 & 17.2 \\
April, 05 & 253 & 31.3 & 10.36 & 25.5 & 580 ) \\
\hline
\end{tabular}

Table 3: Duration of clinical signs and symptoms

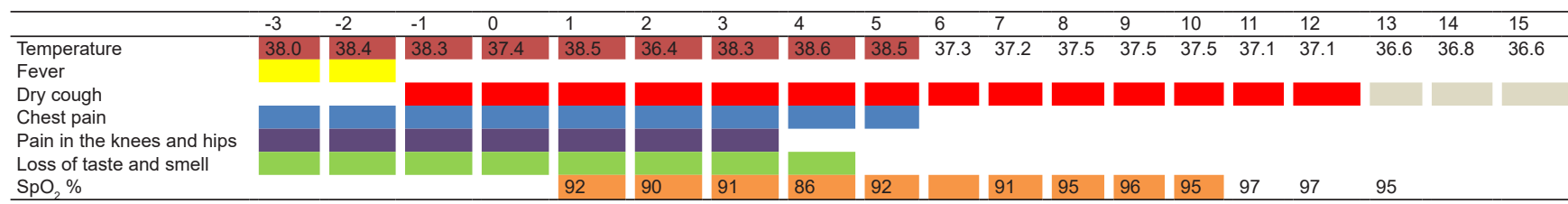

Table 4: Therapeutic approach before and during the hospitalization

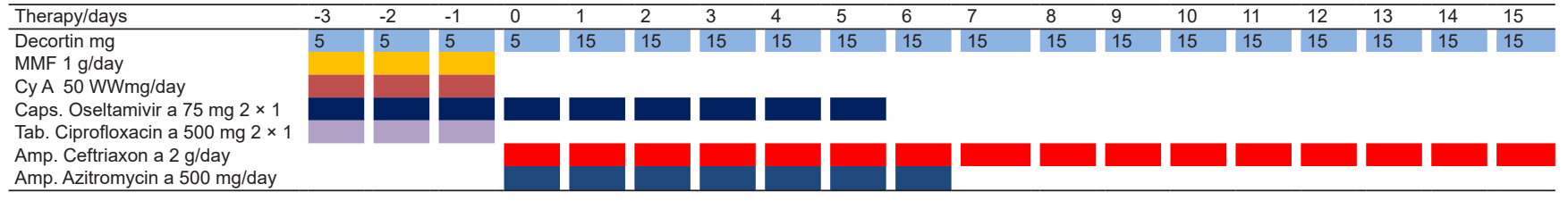

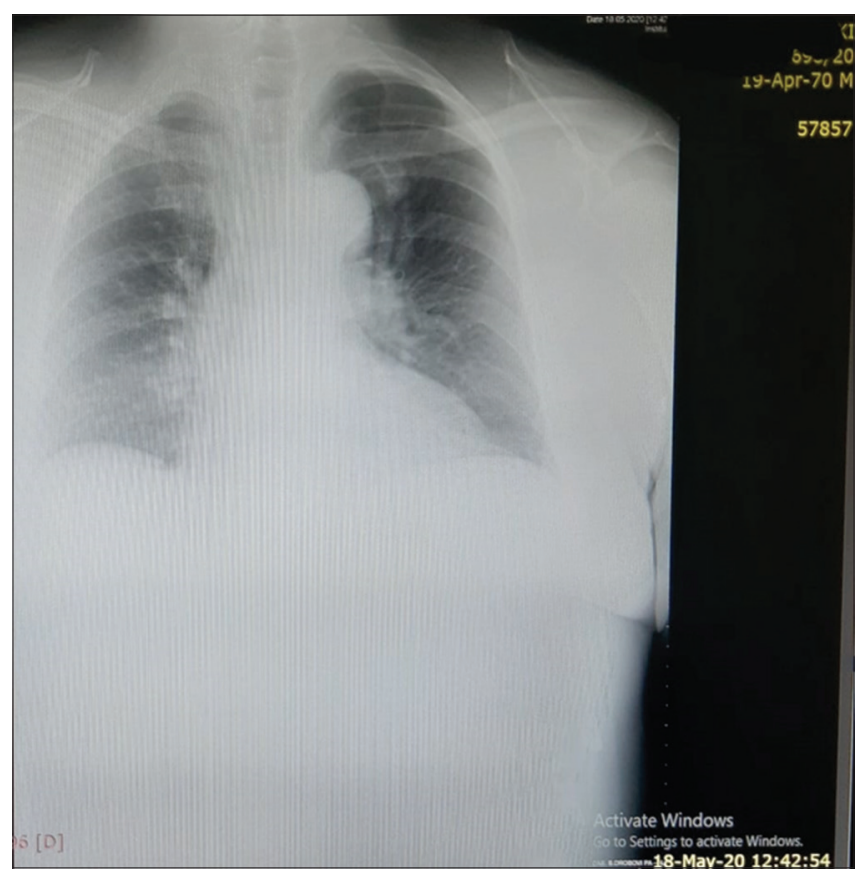

Figure 2: Findings resolved (chest $X$-ray after 24 days)

\section{Discussion}

From the current findings, the biggest risk of becoming infected with COVID-19 disease is through contact with a person with respiratory disease, but the fact that we have a patient with a negative epidemiological survey indicates that the spread of infection by asymptomatic carriers is also important [12]. In terms of gender and age, it has been reported that men and advanced age play a role in the severity of clinical presentation and mortality [13].

Patients with a KT are undergoing permanent immunosuppressive therapy, which causes a state of immunocompromised and often consequently, the infective diseases can have a changed clinical picture. In our first case, the clinical manifestations were fever, high temperature, dry cough, malaise, joint pain, and loss of sense of smell and taste, symptoms identical to those of the general population[2].

Clinical presentation may vary from asymptomatic to severe needing respiratory support. The presence of other comorbidities and conditions, such as high blood pressure, diabetes mellitus, chronic heart disease, chronic respiratory disease, and obesity, has been described as risk factors not only for the onset of COVID-19 but also for the progression and severity of clinical presentation. In our case, the patient was also overweight and had high blood pressure, which was probably the reason for the presentation of moderate to severe clinical picture, but without the need for oxygen support or respirator [14], [15].

Long-term use of immunosuppressive therapy is a reason to reduce $T$ lymphocytes and reduce immunity in patients with transplanted organs. Therefore, modification or total cessation of immunosuppressive therapy, especially of MMF and Cy A, is extremely important in all infections but also in COVID-19 [6], [9]. In our case, the patient was on triple maintenance therapy: Corticosteroids, MMF, and Cy A. During the first three days, the dose of MMF and Cy A was reduced by $50 \%$, and on the day of hospitalization they were discontinued. Table decortin $15 \mathrm{mg} /$ day was established as maintenance therapy. Although experience has suggested that the MMF and calcineurin inhibitor should be discontinued, there are some studies that suggest that Cy A inhibits the replication of the SASR-CoV virus in cell culture [16], [17]. The patient also received ARBs therapy and was discontinued despite insufficient 
evidence that $A C E$ inhibitors and ARBs may cause a more severe clinical picture [18], [19], [20].

So far, it has been reported that there have been a number of disturbances in the biochemical analyses of patients with COVID-19. Lymphocytopenia is the most common finding. Necrosis or apoptosis of the lymphocytes is a possible mechanism. In noncritical patients infected with SARS CoV-2, up to $37 \%$ had mild lymphocytopenia and up to $80 \%$ in critically ill patients. In our case, there was no change in the total number of leukocytes, but there was initially a decrease in the number of lymphocytes to 0.07 , with a gradual increase to 0.20 . An increase in CRP to 87 was registered, followed by its normalization [21], [22].

It is known that SARS-CoV-2 binds to ACE 2 receptors and can enter the cells of the renal tubules and cause acute renal failure [15], [23], [24]. In our patient, graft function remained steady, with serum creatinine values ranged from 104 to $97 \mu \mathrm{moll} / \mathrm{L}$. Mild hypokalemia was noted in the absence of diarrhea and forced diuresis with potassium-sparing diuretics, which may be explained by the above.

SARS-CoV-2 can penetrate and replicate in hepatocytes. In $15 \%$ of patients who do not have a need for intensive care treatment, an increase in AST and ALT is observed. The same goes for the hepatic lesion in our case, with a gradual spontaneous recovery [25].

The presence of coagulopathy in COVID-19 is usually explained by a secondary bacterial infection and an increase in CRP. It is manifested by a decrease in platelet count and an increase in d-dimers, in our case 111 and 2500, respectively, and in some severe cases with the development of disseminated intravascular coagulopathy [26].

Pneumonia was confirmed by the finding of chest X-ray, as in other cases with COVID-19. Since there was no worsening in the condition, there has not been an indication for computer tomography (CT) of the lungs which is otherwise a method with a very high sensitivity of $98 \%$ for diagnosing COVID-19. Despite the extensive findings and the prolonged dry cough, the patient was without oxygen support at all times [27], [28], [29].

The use of a certain group of antibiotics such as the azithromycin has been shown to be effective in treatment. Certain centers have reported the benefits of combining it with chloroquine, but there have been those who have not responded. For severe cases, there are attempts to treat them with antiviral therapy like remdesivir. Special success has been achieved in certain cases with plasma delivery from a convalescent patient rich in antibodies. For cases combined with severe anemia in addition to blood substitution, successful extracorporeal membrane oxygenation (ECMO) treatments have been reported. Furthermore, tocilizumab is reported as an effective treatment in severe patients of COVID-19. However, there is still no specific therapy or vaccine for COVID-19 [30], [31], [32], [33], [34].

\section{Conclusion}

Our first experience showed that the clinical presentation of COVID-19 in a kidney transplanted recipient is the same as in the general population. Treatment with azithromycin and cephalosporin antibiotics has been shown to be effective in the treatment of bilateral pneumonia, along with the modification of immunosuppressive therapy. Since there is still no specific therapy, the latter seems to be of great importance not only for improving immunity but also for a positive clinical outcome. Experience and analysis of several cases are required to reach a conclusion about the treatment and outcome in kidney transplant recipient and COVID 19, which is the limitation in this presentation.

\section{References}

1. Lu R, Zhao X, Li J, Niu P, Yang B, Wu H, et al. Genomic characterisation and epidemiology of 2019 novel coronavirus: Implications for virus origins and receptor binding. Lancet. 2020;395:565-74.

2. Wu D, Wu T, Liu Q, Yang Z. The SARS-CoV-2 outbreak: What we know. Int J Infect Dis. 2020;94:44-8.

PMid:32171952

3. Zaim S, Chong JH, Sankaranarayanan V, HarkyA. COVID-19 and multiorgan response. Curr Probl Cardiol. 2020;45(8):100618. https://doi.org/10.1016/j.cpcardiol.2020.100618

PMid:32439197

4. Chiu MC. Suggested management of immunocompromized kidney patients suffering from SARS. Pediatr Nephrol. 2003;18(12):1204-5. https://doi.org/10.1007/ s00467-003-1325-8

PMid:14663579

5. AlGhamdi M, Mushtaq F, Awn N, Shalhoub S. MERS CoV infection in two renal transplant recipients: Case report. Am J Transplant. 2015;15(4):1101-4. https://doi.org/10.1111/ajt.13085 PMid:25716741

6. Kidney Disease: Improving Global Outcomes (KDIGO) Transplant Work Group. KDIGO clinical practice guideline for the care of kidney transplant recipients. Am J Transplant. 2009;9 (Suppl 3):S1-155. https://doi. org/10.1111/j.1600-6143.2009.02834.x

PMid:19845597

7. Kumar D, Michaels MG, Morris MI, Green M, Avery RK, Liu C, et al. Outcomes from pandemic influenza A H1N1 infection in recipients of solid-organ transplants: A multicentre cohort study. Lancet Infect Dis. 2010;10(8):521-6. https://doi.org/10.1016/ s1473-3099(10)70133-x PMid:20620116

8. Zhu L, Xu X, Ma K, Yang J, Guan H, Chen S, et al. Successfu recovery of COVID-19 pneumonia in a renal transplant recipient with long-term immunosuppression. Am J Transplant. 2020;20(7):1859-63. https://doi.org/10.1111/ajt.15869

PMid:32181990

9. Banerjee D, Popoola J, Shah S, Ster IC, Quan V, Phanish M. COVID-19 infection in kidney transplant recipients. Kidney Int. 2020;97(6):1076-82. https://doi.org/10.1016/j.kint.2020.03.018 


\section{PMid:32354637}

10. Gandolfini I, Delsante M, Fiaccadori E, Zaza G, Manenti L, Antoni AD, et al. COVID-19 in kidney transplant recipients. Am J Transplant. 2020;20:1941-3. https://doi.org/10.1111/ajt.15891 PMid:32233067

11. Ministry of Health of the Republic of Macedonia. Available from: http://www.zdravstvo.gov.mk/korona-virus. [Last accessed on 2020 Jun 01].

12. Shen K, Yang Y, Wang T, Zhao D, Jiang Y, Jin R, et al. Diagnosis, treatment, and prevention of 2019 novel coronavirus infection in children: Experts' consensus statement. World J Pediatr. 2020;16(3):223-31. PMid:32034659

13. Zhou F, Yu T, Du R, Fan G, Liu Y, Liu Z, et al. Clinical course and risk factors for mortality of adult inpatients with COVID-19 in Wuhan, China: A retrospective cohort study. Lancet. 2020;395(10229):1054-62. https://doi.org/10.1016/ s0140-6736(20)30566-3

14. Richardson S, Hirsch JS, Narasimhan M, Crawford JM, McGinn T, Davidson KW, et al. Presenting characteristics, comorbidities, and outcomes among 5700 patients hospitalized with COVID19 in the New York City Area. JAMA. 2020;323(20):2052-9. https://doi.org/10.1001/jama.2020.6775 PMid:32320003

15. Yang $X, Y u$ Y, Xu J, Shu H, Xia J, Liu H, et al. Clinical course and outcomes of critically ill patients with SARS-CoV-2 pneumonia in Wuhan, China: A single-centered, retrospective, observational study. Lancet Respir Med. 2020;8(5):475-81. https://doi. org/10.1016/s2213-2600(20)30079-5

16. De Wilde AH, Zevenhoven-Dobbe JC, Van Der Meer Y, Thiel V, Narayanan K, Makino S, et al. Cyclosporin A inhibits the replication of diverse coronaviruses. J Gen Virol. 2011;92(Pt 11):2542-8. https://doi.org/10.1099/vir.0.034983-0 PMid:21752960

17. Tanaka Y, Sato Y, Sasaki T. Suppression of coronavirus replication by cyclophilin inhibitors. Viruses. 2013;5(5):1250-60. https://doi.org/10.3390/v5051250 PMid:23698397

18. Patel AB, Verma A. COVID-19 and angiotensin-converting enzyme inhibitors and angiotensin receptor blockers: What is the evidence? JAMA. 2020;323(18):1769-70. https://doi. org/10.1001/jama.2020.4812

PMid:32208485

19. Gurwitz D. Angiotensin receptor blockers as tentative SARS-CoV-2 therapeutics. Drug Dev Res. 2020;81(5):537-40. https://doi.org/10.1002/ddr.21656 PMid:32129518

20. American College of Cardiology. HFSA/ACC/AHA Statement Addresses Concerns Re: Using RAAS Antagonists in COVID19. ACC News Story; 2020. Available from: https://www.viajwat. ch/2REZU2H. https://doi.org/10.1016/j.cardfail.2020.04.013. [Last accessed on 2020 Jun 01].

21. Jin YH, Cai L, Cheng ZS, Cheng H, Deng T, Fan YP, et al. A rapid advice guideline for the diagnosis and treatment of 2019 novel coronavirus (2019-nCoV) infected pneumonia (standard version). Mil Med Res. 2020;7:4.

22. Mardani R, Ahmadi Vasmehjani A, Zali F, Gholami A, Mousavi Nasab SD, Kaghazian $\mathrm{H}$, et al. Laboratory parameters in detection of COVID-19 patients with positive RT-PCR; a diagnostic accuracy study. Arch Acad Emerg Med. 2020;8(1):e43.
PMid:32259132

23. Li W, Moore M, Vasilieva N, Sui J, Wong SK, Berne MA, et al. Angiotensin-converting enzyme 2 is a functional receptor for the SARS coronavirus. Nature. 2003;426(6965):450-4. https://doi. org/10.1038/nature02145

PMid:14647384

24. Raj VS, Mou H, Smits SL, Dekkers DH, Muller MA, Dijkman $\mathrm{R}$, et al. Dipeptidyl peptidase 4 is a functional receptor for the emerging human coronavirus-EMC. Nature. 2013;495(7440):251-4. https://doi.org/10.1038/nature12005 PMid:23486063

25. Zang C, Shi L, Wang FS. Liver injury in COVID-19: Management and challenges. Lancet Gastroenterol Hepatol. 2020;5(5):428-30.

PMid:32145190

26. Levi M, Thachil J, Iba T, Levy JH. Coagulation abnormalities and thrombosis in patients with COVID-19. Lancet Haematol. 2020;7(6):e438-40. https://doi.org/10.1016/ s2352-3026(20)30145-9

PMid:32407672

27. Huang C, Wang Y, Li X, Ren L, Zhao J, Hu Y, et al. Clinica features of patients infected with 2019 novel coronavirus in Wuhan, China. Lancet. 2020;395(10223):497-506. https://doi. org/10.1016/s0140-6736(20)30183-5

28. Chung $M$, Bernheim $A$, Mei $X$, Zhang $N$. CT imaging features of 2019 novel coronavirus (2019-nCoV). Radiology. 2020;295(1):202-7.

PMid:32017661

29. Ai T, Yang Z, Hou H, Zhan C, Chen C, Lv W, et al. Correlation of chest CT and RT-PCR testing for coronavirus disease 2019 (COVID-19) in China: A report of 1014 cases. Radiology. 2020;296(2):E32-40. https://doi.org/10.1148/radiol.2020200642 PMid:32101510

30. Gautret P, Lagier JC, Parola P, Hoang VT, Meddeb L, Mailhe M, et al. Hydroxychloroquine and azithromycin as a treatment of COVID-19: Results of an open-label non-randomized clinical trial. Int J Antimicrob Agents. 2020;56(1):105949. https://doi. org/10.1016/j.ijantimicag.2020.105949

PMid:32205204

31. Wang $Y$, Zhang D, Du G, Du R, Zhao J, Jin $Y$, et al Remdesivir in adults with severe COVID-19: A randomised, double-blind, placebo-controlled, multicentre trial. Lancet. 2020;395(10236):1569-78. https://doi.org/10.341 0/f.737842320.793574054

32. Shen C, Wang Z, Zhao F, Yang Y, Li J, Yuan J, et al. Treatment of 5 critically ill patients with COVID-19 with convalescent plasma. JAMA. 2020;323(16):1582-9.

PMid:32219428

33. Kowalewski M, Fina D, Słomka A, Raffa GM, Martucci G, Lo Coco V, et al. COVID-19 and ECMO: The interplay between coagulation and inflammation-a narrative review. Crit Care. 2020;24(1):205. https://doi.org/10.1186/s13054-020-02925-3 PMid:32384917

34. Xu X, Han M, Li T, Sun W, Wang D, Fu B, et al. Effective treatment of severe COVID-19 patients with tocilizumab. Proc Natl Acad Sci U S A. 2020;117(20):10970-5. https://doi. org/10.1073/pnas.2005615117

PMid:32350134 